\title{
Adzan : Study Of Musical, Culture, and Technology
}

\author{
$1^{\text {st }}$ Mukhlis Hasbullah ${ }^{1}, 2^{\text {nd }}$ Herna Hirza $^{2}, 3^{\text {rd }}$ Ifwanul Hakim $^{3}$ \\ \{perigi.music@gmail.com ${ }^{1}$ \} \\ Universitas Negeri Medan, Indonesia ${ }^{1,2,3}$
}

\begin{abstract}
This study aims to conduct an assessment of the art of Adzan in North Sumatra Province, Indonesia, by looking at 3 aspects; forms of music, cultural influences, and the development of digital technology. The objectives of this study consist of: 1) finding the melodic style of the adzan in North Sumatra; 2) determine the influence of the traditional vocal art of North Sumatra on the style of adzan in North Sumatra. The method used in this research is a qualitative approach. The process of searching for data and information was carried out through field observations by recording the audio of the adzan at mosques in North Sumatra as well as interviews with several related sources. The research process consists of the preparation stage, the data collection stage, the data analysis stage, to the stage of concluding the results. Keywords : adzan, music analysis, digital technology.
\end{abstract}

Keywords: Musical, culture, technology.

\section{Introduction}

Adzan is one of the ritual processes of worship in Islam. Conceptually, Arisandi [1] explains that the adzan is a sound whose content is dominated by the sentence of tauhid and is equipped with the teachings of prayer and invitation to achieve success in life in this world and the hereafter. While iqamah is a call of notification to the audience (congregation) to be ready to stand to perform prayers, with the pronunciation that has been determined by the Islamic rules [2].

The adzan contains praises to Allah which are sound aloud from the Mosque with the aim of inviting the people to prayers. The complete text of the adzan is as follows.

Allahu Akbar, Allahu Akbar (God is Great, God is Great)

Asyhadu An La Ilaha IllAllah (I Bear Witness That No God Except Allah)

Asyhadu Anna Muhammadan Rasulullah (I Bear Witness That Muhammad is The Messenger Of Allah )

Hayya 'Alas Sholah (Let's to Prayer)

Hayya 'Alal Falah (Let's to Victory)

Allahu Akbar, Allahu Akbar (God is Great, God is Great)

La Ilaha IllAllah (There is No God Except Allah)

In a day and night, the adzan is performed five times, that is, at each time of prayers; subuh, dzuhur, 'asar, maghrib and 'isya. As part of the communication function, the call to prayer must reach the ears of the people both in the house, in the market, in the fields and on the way.

The melody of the adzan is sung in different modes. The song or rhythm commonly used is the Arabian mode as its native land. These Arabic modes are called nagham. 
Originally this nagham was brought by the Qori from Egypt and spread this knowledge in 1973. This popularly called nagham Quran or Tahsin As-Shout which means to improve the voice in reading the Qur'an.

The person who recites the adzan is called muadzin. He should have the capacity for both technical reading skills of Quran and its manners. As explained by Imam Hanafi that when becoming a muadzin is very strict. However, when forced, these requirements may not be met because it is very non-binding. The requirements to become a muadzin according to Imam Hanafi are as follows:

a. It is time for prayer. Because the full validity of the adzan is that the time for prayer has entered, so the adzan before the time of prayer is entered is invalid.

b. Intention to adzan. Someone who is going to adzan intends in his heart (not with a certain lafadz take him to do the adzan sincerely for Allah alone.

c. Revealed in Arabic. According to some scholars, the adzan is invalid if it is uttered other than Arabic. Among the schlars who hold this opinion are scholars from the Hanafi, Hambali, and Shafii schools.

d. The adzan should be free from pronunciation errors which can change the meaning of the adzan. The sentences of adzan must be pronounced clearly and correctly.

e. The words are pronounced in the order described in the authentic hadiths.

f. The pronunciations are said in sequence, meaning that one pronunciation with another is said in sequence without being separated by a word or deed outside the adzan. However, it is permissible to say or do something light, such as sneezing.

g. The adzan is given to people who are not in the place of the muadzin. The call to prayer echoed by the muadzin must be heard by people who are not in the place where the muadzin is doing the adzan. This can be done by raising the voice or by using a loudspeaker.

\section{Method}

North Sumatra is an area occupied by multicultural people. The ethnics that inhabit this province include Melayu, Mandailing, Karo, Pak Pak, as well as immigrant tribes such as Minangkabau, Aceh, and Java. If we trace the coast to the mountains of North Sumatra, we will get a rich variety of traditional music. One of them is the mode or melody of song.

North Sumatra as a locus inhabited by dozens of ethnicities and sub-ethnics with each musical richness, allows new perceptions in interpreting the adzan. This study wants to test this hypothesis. Does the traditional vocal art of the ethnic groups in North Sumatra affect the style of the adzan in North Sumatra or not. The test will be carried out by collecting audio data for the adzan from various mosques in several areas in North Sumatra. To strengthen the data, the researcher also conducted interviews with several muadzin in these mosques. Using a simple random sampling method, the sample in this study was determined to be mosques in the Karo, Simalungun and Mandailing ethnic areas.

\section{Result and Discussion}


To answer the hypothesis of this research, we first need to describe the Arabic mode (scale) and the vocal mode of the North Sumatran traditions (Karo, Simalungun and Mandailing). Then we will compare both of them with the mode used by the muadzin in the mosques in Karo, Simalungun, and Simalungun. Later we will find out which mode is dominantly used by muadzin in these three regions of North Sumatra.

\subsection{Arabic Scale}

Nagham or Maqam is a scale that has a very diverse treasure. Among the most frequently used in reading Quran and call the adzan by muadzin from Mecca and Medina are hijaz, bayati, nahawand, jaharkah, rast and saba.

a. Hijaz

Hijaz mode is one of the main modes in Arabic maqam. The scale tone consists of DEb-F\#-G-A-Bb-C-D

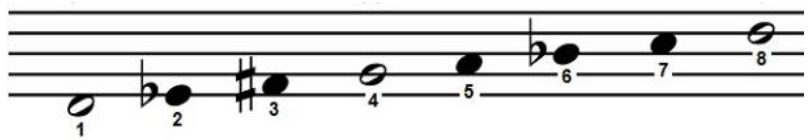

Fig. 1. Scale of hijaz (source : maqamworld.com). [3]

b. Bayati

The scale of bayati is D-Eb-F-G-A-Bb-C-D

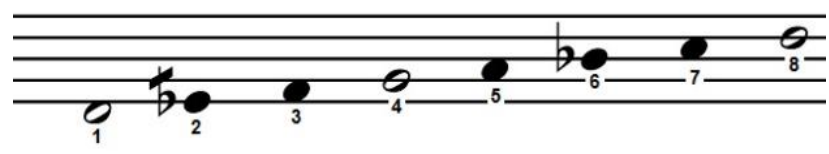

Fig. 2. Scale of bayati [3].

c. Nahawand

The scale of Nahwand is C-D-Eb-F-G-Ab-B-C

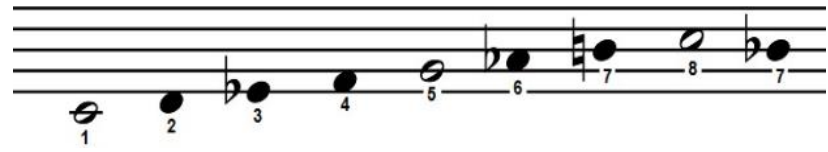

Fig. 3. Scale of nahawand [3].

d. Rast

The scale of rast is C-D-Eb-F-G-A-Bb-C

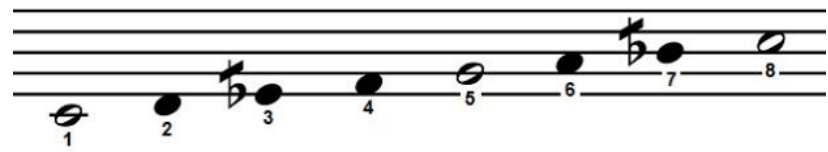

Fig. 4. Scale of rast [3]. 
e. Saba

The scale of saba is D-Eb-F-Gb-A-Bb-C-Db-D

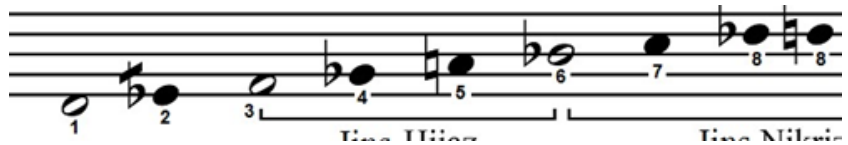

Fig. 5. Scale of saba [3].

\subsection{Traditional Music of North Sumatera}

3.2.1 Karo. Karo is one of several ethnics that inhabit the province of North Sumatra. Karo is also a term for one district administrative area, namely Karo district whose territory covers the entire Karo highlands. The area inhabited by the Karo tribe is bordered to the east by a road that separates the highlands from Serdang. In the south it is roughly bordered by the Biang river (which is named the Wampu river, when it enters Langkat), in the west it is bordered by Mount Sinabung and in the north the area extends to the lowlands of Deli and Serdang [4]. In Karo music culture there is also a song which also has an important role in a ceremony in Karo society. The vocal art that developed in the Karo people is known as rende (singing). Vocal art in Karo people is usually used in wedding ceremonies, funerals, entertainment ceremonies and erpangir kulau ritual. Sinulingga (2016) in his analysis of Karo folklore songs, concluded that Karo folklore songs use 5 tones (phentatonic scale), consisting of B-C-E-Fis-and G.

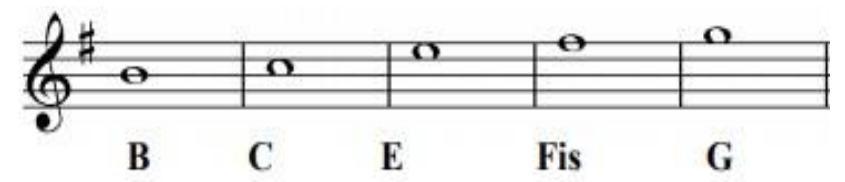

Fig. 6. Scale of karo traditional music.

3.2.2 Simalungun. Simalungun is one of five Batak ethnic groups consisting of Toba Mandailing/Angkola, Simalungun, Karo and Pakpak/Dairi [5]. Vocal art in the Simalungun ethnic group is called inggou. Inggou is a way of singing with the typical rhythm of Simalungun [6]. There are two types of inggou, namely ilah (singing together) and doding (singing solo). Ilah is sung in groups in a large yard in a village and sung by young people on moonlit nights or at entertainment events such as rondang bittang events, sung while mentoring. The song of the gods is presented without musical accompaniment, as the usual tempo setting is by clapping. Doding is a solo singing performed by someone when he is alone. Doding can be sung with musical accompaniment such as sulim, husapi, sarunei, and others. According to Adimurti (2005), in Simalungun Batak music, the scales used are pentatonic scales do-re-mi-sol la (without fa and si tones).

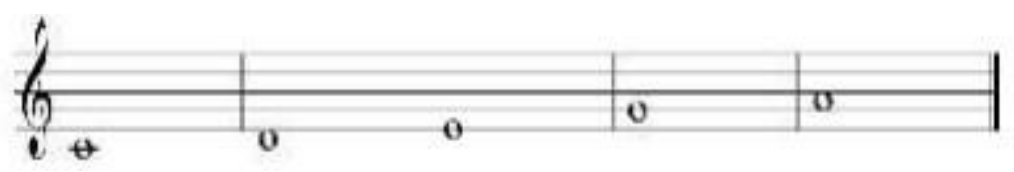


Fig. 7. Scale of simalungun traditional music.

3.2.3 Mandailing. In particular, the Mandailing community uses the term ende to mention all kinds of singing or vocal arts found in that ethnic. Although in each song performed by the community which has a different function. Pasaribu [8] writes that the singing of andung (wailing) is performed in the traditional ceremony of siluluton (grief). The ungut ungut song is usually sung by young people (although anyone can bring it) as a consolation song that depicts grief in terms of love, and is sung not in public or privately only. In addition, there is what is called bue-bue, which is the song a mother sings when she wants to put her baby to sleep. In Mandailing traditional vocal art, the scales used are the penthatonic major scale consisting of do, re, mi, fa, and sol.

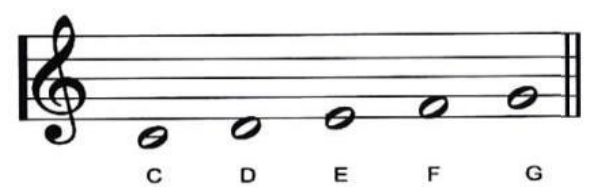

Fig. 8. Scale of mandailing traditional music.

\subsection{Analysis of Azdan}

For each ethnic area, the researcher chose the adzan from 3 different mosques to be the object of analysis. Furthermore, to facilitate writing, the following code will be used.

a. The Karo ethnic area is written with mosque 1, mosque 2, and mosque 3; Mosque 1 is located in Barusjahe, Karo Regency. From mosque 1 found the pattern of the melodic of adzan as follows:

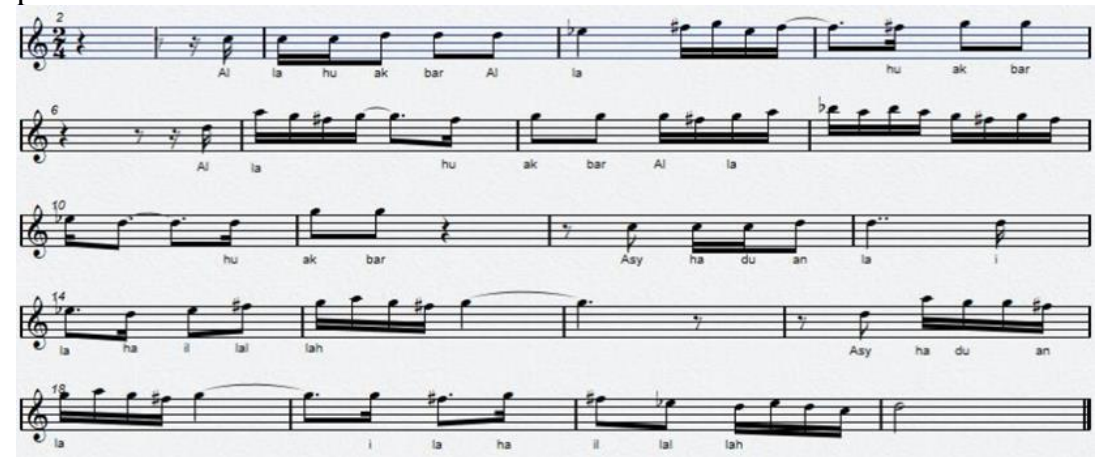

Fig. 9. Notation of Adzan at Barusjahe mosque.

Looking from the tone of the melodic line used, those are D-Eb-F\#-G-A-Bb-C, found the pattern of the adzan in mosque 1 used is Hijaz. Mosque 2 is located in Merek, Karo Regency. From mosque 2 found the pattern of the melodic of adzan as follows: 


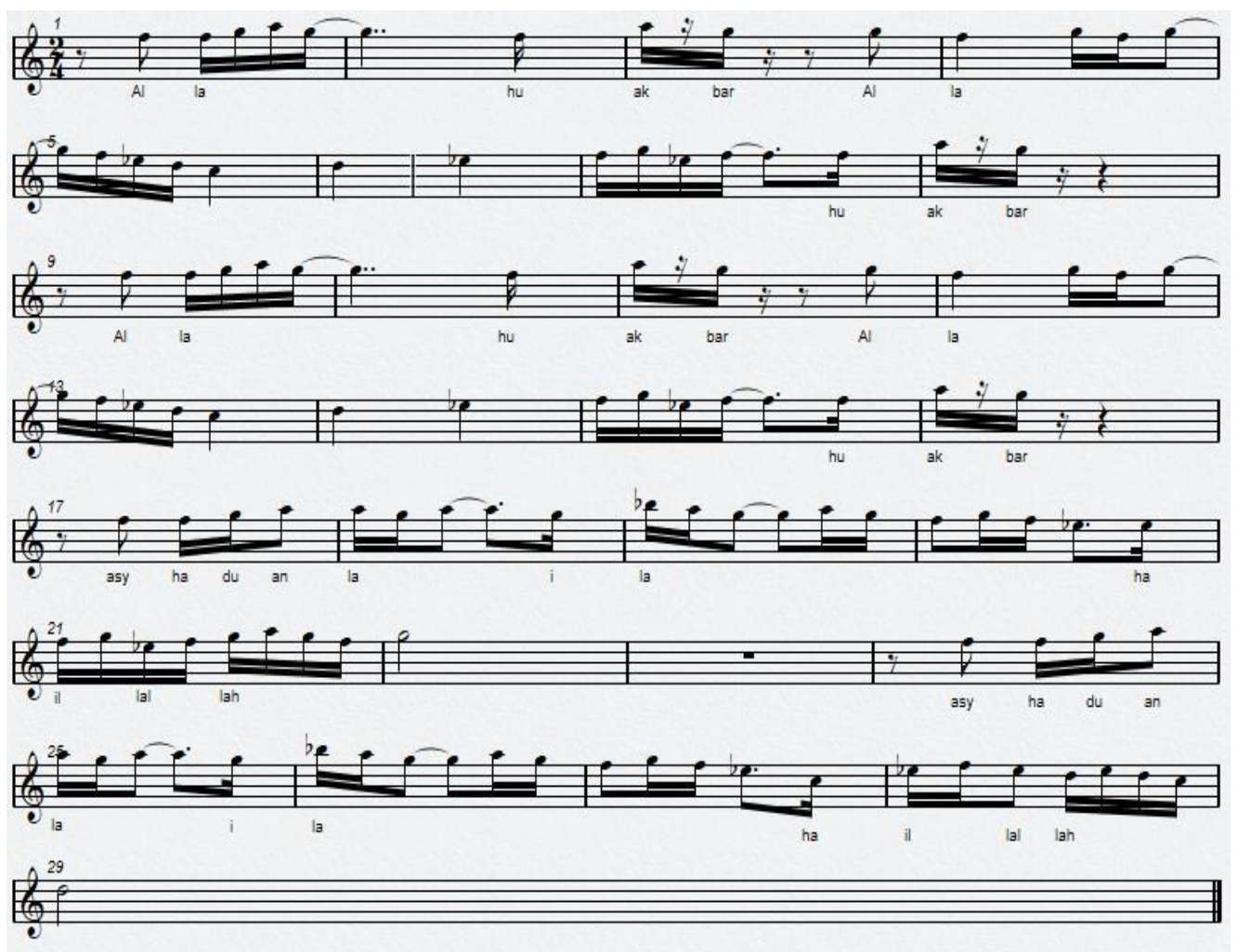

Fig. 10. Notation of Adzan at Merek mosque.

Looking from the tone of the melodic line used, those are D-Eb-F-G-A-Bb, found the pattern of the adzan in mosque 2 used is Bayati. Mosque 2 is located in Kabanjahe, Karo Regency. From mosque 2 found the pattern of the melodic of adzan perfectly same as mosque 1, that is Hijaz style of melodic (see figure 9). When we look at the 3 mosques in these 3 ethnic Karo regions, the dominant use of the adzan melody is the Arabian style, namely hijaz and bayati.

b. The Simalungun ethnic area is written with mosque 4, mosque 5, and mosque 6 Mosque 4 is located in Siantar, Simalungun Regency. From mosque 4 found the pattern of the melodic of adzan as follows: 


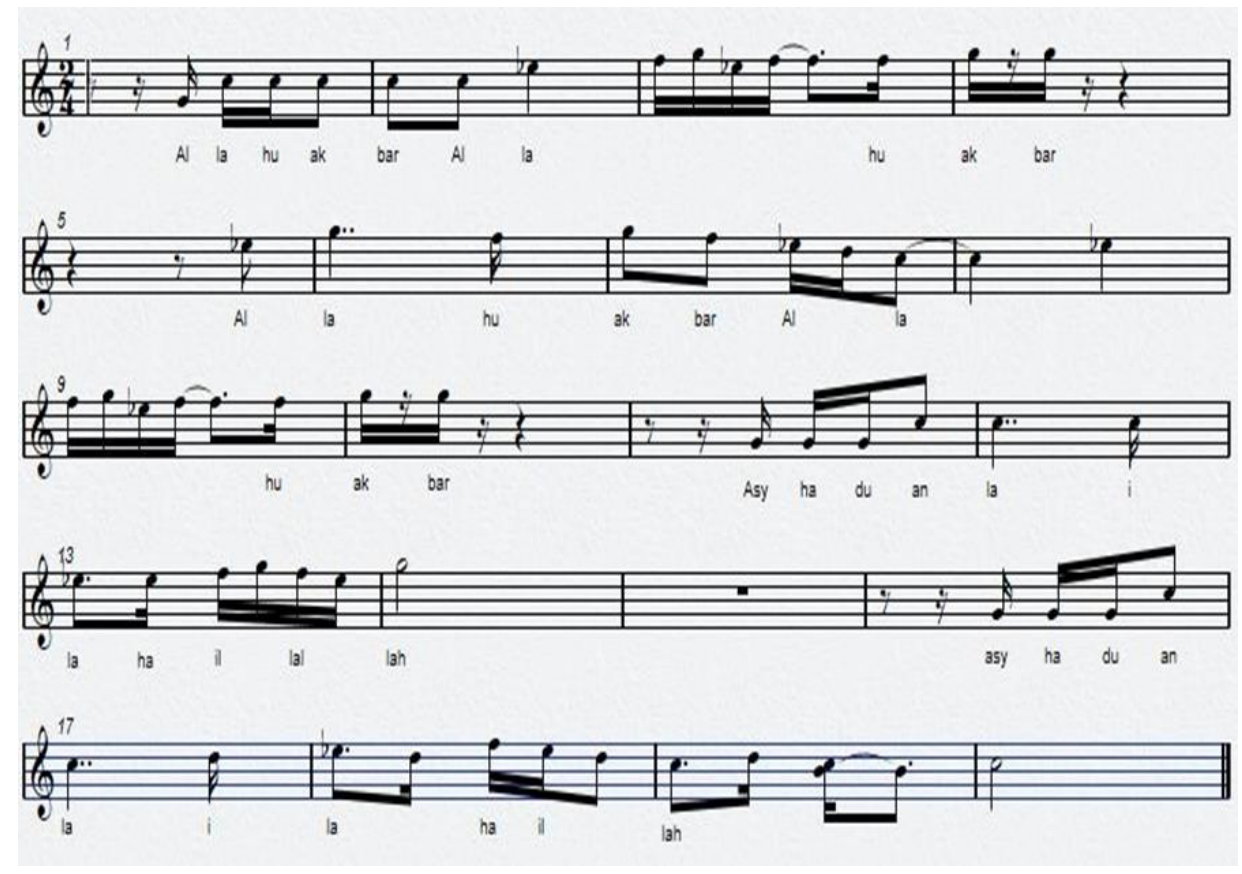

Fig. 11. Notation of Adzan at Siantar mosque.

Looking from the tone of the melodic line used, those are C-D-Eb-F-G-B, found the pattern of the adzan in mosque 2 used is Rast. Mosque 5 is located in Sidamanik, Simalungun Regency. From mosque 5 found the melodic of hijaz combined with bayati (see figure 9 and 10). Mosque 6 is located in Tapian Dolok, Simalungun Regency. From mosque 6 found the melodic of bayati (see figure 10). Looking at the 3 mosques in these 3 Simalungun ethnic regions, it was found that the use of Arabic rhythms is still dominant in this region.

c. The Mandailing ethnic area is written with mosque 7 , mosque 8 , and mosque 9 . Mosque 7 is located in Sipirok, South Tapanuli Regency. From mosque 7 found the adzan with the Rast melodic scale as well as in mosque 4 (see figure 11). The maqam of nahawand with the scale of C-D-Eb-F-G-Ab tone is heard at mosque 8, located in Batang Toru, South Tapanuli Regency. If written in notation the melodic pattern of the adzan at mosque 8 is as follows: 


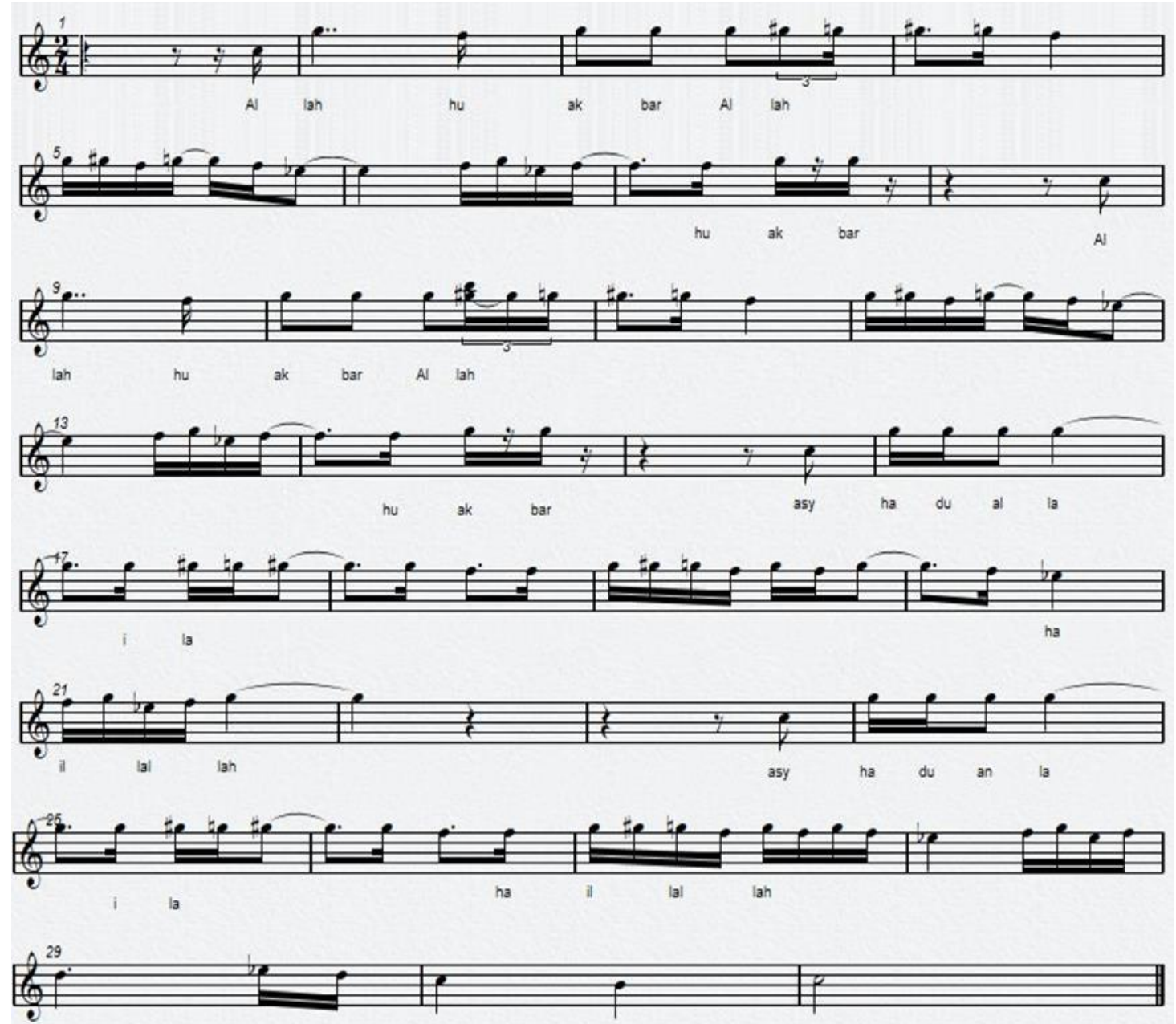

Fig. 12. Notation of Adzan at Sipirok mosque.

Like the mosque 4, the muadzin at mosque 9 located in Sayur Matinggi, South Tapanuli Regency, also uses the maqam Rast when sounding the adzan. As well as previous 2 ethnic areas, the melodic of adzan in these 3 Mandailing ethnic regions is also dominated by the Arabian melodic style. From the data above, it is not found the influence of the vocal arts of the Karo, Mandailing, and Simalungun traditions on nine mosques in this three region. The mosques in these three ethnic areas actually use the Arabic scale pattern in sounding adzan. Based on the results of interviews with several muadzin in these mosques, researchers tried to describe some of the reasons they use Arabic modes, as follows:

- The muadzin of mosque 3, a 15-year-old youth, explained that his background as a santri (student) in a modern Islamic boarding school in Medan made him more familiar with hearing the Arabic-style of adzan, both from the Ustadz (teacher) and seniors at his school (pesantren). In addition, in Islamic boarding schools they are 
also taught the art of reading Quran using Arabic maqam such as Nahawand, Hijaz, and Bayati.

- The muadzin of mosque 6, a 60 year old, has a conservative reasons. For him, the traditional songs in Simalungun are affiliated with church songs, so it is feared to cause negative perceptions from Muslim people.

- The muadzin of the mosque 8, a 20 years young man, said that although he is not from a Islamic school (pesantren), he likes to hear murottal (recitation of the Quran) and the adzan from the great imams of mosques in Mecca and Medina through digital platforms such as YouTube and Instagram.

\section{Conclusion}

As a conclusion, it can be said that the existence of ethnic music and traditional songs of North Sumatra has no impact on the style of melodic style of adzan in North Sumatra mosques. The muadzins in North Sumatra prefer to use Arabic rhythms as the place of origin of the birth of Islamic civilization rather than the melody of traditional singing of their hometowns.

There are several factors that influence this condition, including formal education (pesantren education), the development of digital technology (social media), the influence of spectacles and favorite figures, as well as fanaticism and conservation of religious identity by adherents of Islam in North Sumatra.

\section{References}

[1] Arisandi DH. Tradisi adzan tumbal di dusun giriliyo, desa wukirsari, kecamatan imogiri, kabupaten bantul. Yogyakarta; Skripsi. Universitas Islam Negeri Sunan Kalijaga; 2013.

[2] Iderus M. Meningkatkan kemampuan adzan dan iqamah dengan metode demonstrasi dan drill pada siswa kelas v sdn 1 lumbang kecamatan muara uya kabupaten tabalong. Banjarmasin; Skripsi, Tarbiyah dan Keguruan. Skripsi. Institut Agama Islam Negeri Antasari Banjarmasin; 2014.

[3] Maqam World. Arabic Maqam World. Available from www.maqamworld.com.

[4] Tarigan S. Lentera kehidupan orang karo dalam berbudaya. Medan; 2009.

[5] Bangun T. Adat dan upacara perkawinan masyarakat batak karo. Jakarta: Kesaint Blanc; 1986.

[6] Hutabarat SI. Komposisi musik programa dengan konsep penggabungan musik barat dan musik tradisional simalungun. Laporan Disertasi; 2008.

[7] Adimurti JT. Inkulturasi musik gereja di batak toba dan simalungun. Harmonia. Journal of arts research and education. 2005; 6(3).

[8] Pasaribu BM. Pluralitas musik etnik: Batak-toba, mandailing, melayu, pakpak-dairi, angkola, karo, simalungun. Pusat Dokumentasi dan Pengkajian Kebudayaan Batak Universitas HKBP Nommensen: Medan; 2004. 